\title{
The effect of ultrasound treatment on microbial and physicochemical properties of Iranian ultrafiltered feta-type cheese
}

\author{
A. Jalilzadeh, ${ }^{*}$ J. Hesari, ${ }^{* 1}$ S. H. Peighambardoust, ${ }^{*}$ and I. Javidipourt \\ *Department of Food Science, College of Agriculture, University of Tabriz, Tabriz 5166614766, Iran \\ †Department of Food Engineering, Faculty of Engineering, Van Yüzüncü Yıl University, 65080 Van, Turkey
}

\begin{abstract}
Pasteurization failures in the dairy industry have been reported in many previous studies. Hence, ultrasound, as a nonthermal alternative to pasteurization, has been studied in recent years. In this research, retentate of ultrafiltered milk was pasteurized, inoculated with Escherichia coli O157:H7, Staphylococcus aureus, Penicillium chrysogenum, or Clostridium sporogenes, and then treated with ultrasound for $20 \mathrm{~min}$ at frequencies of 20,40 , and $60 \mathrm{kHz}$ and intensity of $80 \%$. Microbial and physicochemical properties of the subsequently produced ultrafiltered white cheeses were investigated throughout $60 \mathrm{~d}$ of ripening. Sonication at 20,40, and $60 \mathrm{kHz}$ reduced counts of E. coli $\mathrm{O} 157: \mathrm{H} 7$, S aureus, $P$. chrysogenum, and $C l$. sporogenes by $4.08,4.17$, and 4.28 $\log ; 1.10,1.03$, and $1.95 \log ; 1.11,1.07$, and $1.11 \log$; and $2.11,2.03$, and $2.17 \mathrm{log}$, respectively. Sonication improved the acidity of ripened cheese, and sonicated samples had lower $\mathrm{pH}$ values than control samples at the end of storage. Sonication did not affect fat in dry matter or the protein content of cheese during ripening, but it did accelerate lipolysis and proteolysis; the highest rates of lipolysis index (free fatty acid content) and proteolysis index (water-soluble nitrogen) were observed on d 60 of ripening for samples sonicated at 60 $\mathrm{kHz}$. Sonication did not affect cohesiveness or springiness of cheese samples, but hardness and gumminess increased in the first $30 \mathrm{~d}$ and then decreased until 60 $\mathrm{d}$ of storage. Furthermore, ultrasound treatment improved organoleptic properties of the cheese. In terms of overall acceptance, samples sonicated at $60 \mathrm{kHz}$ received the highest sensorial scores. Results showed that sonication can improve microbial, physicochemical, and sensorial properties of ultrafiltered white cheese.
\end{abstract}

Key words: ultrasound, ultrafiltered white cheese, Escherichia coli, Staphylococcus aureus

Received December 26, 2017.

Accepted February 23, 2018.

${ }^{1}$ Corresponding author: jhesari@tabrizu.ac.ir

\section{INTRODUCTION}

Iranian ultrafiltered (UF) feta cheese made from bovine milk is manufactured in modern dairy plants from ultrafiltered and pasteurized milk with starter cultures and commercial microbial rennet. According to the Iranian national standard, the main characteristics of this type of cheese are a minimum of $34 \%$ (wt/wt) total solids, a protein content of $12 \%$, maximum acidity of $1.80 \%$ lactic acid, and a pH of 4.60 to 5.20 (ISIRI, 2015). Microbial contamination is one of the main problems in UF white cheese. Although Escherichia coli is reported to be destroyed by pasteurization, some strains of $E$. coli, including the pathogenic strain O157:H7, can survive and form biofilms within pasteurization equipment (Dewanti and Wong, 1995). Robinson (2014) reported that E. coli O157:H7 was completely inhibited in scalded-brined cheese within $30 \mathrm{~d}$ of ripening; however, the same pathogen remained active in the unscalded cheese, even at high salt concentrations (i.e., $17.5 \% \mathrm{NaCl}$ ). Survival of Staphylococcus aureus in white-brined cheeses, even at low $\mathrm{pH}$ and high salt levels, has been observed (Robinson, 2014). Some species of Clostridium, including Cl. tyrobutyricum, Cl. sporogenes, Cl. beijerinckii, and $\mathrm{Cl}$. butyricum, are thought to cause late blowing in cheeses (Le Bourhis et al., 2005, 2007). Clostridium spores are able to survive the pasteurization process (Garde et al., 2011). Ultrafiltered white cheese, because of its low $\mathrm{pH}$ and high moisture content, is susceptible to contamination by filamentous fungi and yeasts (Sajadi et al., 2015). Penicillium, including mycotoxigenic strains, is the genus of molds most frequently isolated from cheese samples. Molds and yeasts include strains with psychrotrophic characteristics that can grow during cold storage (Pintado et al., 2010).

In terms of cost, ultrasound equipment is not expensive compared with other technologies and the main operation cost of ultrasound systems is electrical power, which makes it is cost-efficient and environmentally friendly compared with thermal pasteurization. Highpower ultrasound can be coupled with heat (thermosonication) to obtain the desired results in microbial 
deactivation and retaining the nutritional attributes of the product. Thermosonication also can prove to be a cost-efficient technology because the process temperature is reduced by use of ultrasonication compared with that of thermal pasteurization. Bacteria such as $E$. coli O157:H7, Salmonella typhimurium, Listeria monocytogenes (Sagong et al., 2011), and S. aureus (Li et al., 2017), and molds and yeasts such as Penicillium, Aspergillus (Herceg et al., 2015), and Saccharomyces cerevisiae (Piyasena et al., 2003) can be deactivated by ultrasound, depending on the processing conditions.

To the best of our knowledge, there are no published studies on the effect of ultrasound on inactivation of spoilage microorganisms or on the possible effects of ultrasound on the physical and chemical properties of UF white cheese during ripening. Therefore, the objective of this work was to investigate the effects of different ultrasound frequencies on UF retentate of milk and to study the physical, chemical, and microbial properties of UF cheese during the ripening period.

\section{MATERIALS AND METHODS}

\section{Microbial Strains}

Microbial strains, including E. coli O157:H7, S. aureus PTCC 1189, Cl. sporogenes PTCC1651, and Penicillium chrysogenum PTCC 5035, were obtained from the Iranian Research Organization for Science and Technology (Tehran) in freeze-dried form. Tryptic soy broth was used for pre-culture of bacteria and specific culture media were used for enumeration of microorganisms. Staphylococcus aureus and E. coli were cultured in Baird Parker agar and MacConkey agar, respectively, and incubated at $37^{\circ} \mathrm{C}$ for $24 \mathrm{~h}$. All medium cultures prepared from Merck Company (Frankfurt, Germany). Penicillium chrysogenum were enumerated after incubation in potato dextrose agar (at $25 \pm 1{ }^{\circ} \mathrm{C}$ for $72 \mathrm{~h}$. Clostridium sporogenes were cultured under anaerobic conditions (in anaerobe jar by using GasPack A, Merck Co.) in sulfite-cycloserine agar at $37^{\circ} \mathrm{C}$ for 24 $\mathrm{h}$. The mixture of thermophilic Lactobacillus bulgaricus and mesophilic Lactococcus lactis from the Chr. Hansen Co. (Hørsholm, Denmark) was prepared and used as a starter culture. The starter culture enumeration was done after incubation in M17 agar at $37^{\circ} \mathrm{C}$ for $48 \mathrm{~h}$.

\section{Sonication and Cheese Making}

The retentate was prepared by Iran Dairy Industry Inc. (Est Azarbyajan Pegah Co., Tabriz, Iran) and used for production of Iranian UF white cheese. The UF membrane cartridges were of the spiral wound type
(UFPH20, Invensys APV, Silkeborg, Denmark), and the membrane had a nominal molecular weight cutoff of approximately $20 \mathrm{~kg} / \mathrm{mol}$ with a surface area of $16.9 \mathrm{~m}^{2}$. The ultrafiltration unit was operated at inlet and outlet pressures of 530 and $170 \mathrm{kPa}$, respectively. Retentate of UF milk (containing 16\% fat, $13 \%$ protein, and $34 \% \mathrm{DM})$ was pasteurized $(78,1 \mathrm{~min})$, inoculated with E. coli O157:H7, S. aureus, Cl. sporogenes, or $P$. chrysogenum microorganisms and then was subjected to ultrasonication at frequencies of 20,40 , and $60 \mathrm{kHz}$ (for $20 \mathrm{~min}$ at an intensity of $80 \%$ ) using a Sonopuls Ultrasonic Homogenizer (model no. HD2200, Bandelin Company, Berlin, Germany). The booster horn and probe of the sonicator were disassembled, washed completely, and sterilized at $121^{\circ} \mathrm{C}$ for $20 \mathrm{~min}$ by using an autoclave (model no. REOT25, Shimaz Company, Tehran, Iran) before each treatment. Cheesemaking was carried out (at Pegah Co.) as shown in Figure 1, following the method of Hesari et al. (2006).

\section{Analysis of Cheese Samples}

The $\mathrm{pH}$ of the cheese was measured by direct insertion of an electrode (model HI99165, Hanna Instruments, Singapore) into grated cheese after calibration with standard buffers $\mathrm{pH} 4$ and 7 at 20 to $30^{\circ} \mathrm{C}$. Titratable acidity was determined (g/100 $\mathrm{g}$ of lactic acid) using the method described in AOAC International (1995). Moisture content of cheese samples was analyzed by oven drying method at $102 \pm 2^{\circ} \mathrm{C}$. Fat and salt contents of the cheese were determined by the Van Gulik method (Ardo and Polychroniadou, 1999) and titration with $\mathrm{AgNO}_{3}$ (Bradley et al., 1993), respectively. The total concentration of free fatty acids (FFA) in the cheese was determined by titrating the acidity in the cheese fat with $0.05 \mathrm{~N}$ ethanolic $\mathrm{KOH}$ using the method described by Nunez et al. (1986); results were expressed as the percentage oleic acid in cheese fat (IDF, 1989). The $\mathrm{pH}$ 4.6-soluble nitrogen of samples was obtained by a slight modification of the procedure of Kuchroo and Fox (1982), as described by Sousa et al. (2001). The NPN fraction was obtained from the water-soluble nitrogen (WSN) by addition of trichloroacetic acid until obtaining a final concentration of $12 \%$. Total nitrogen (TN), WSN, and NPN were determined by the Kjeldahl method (IDF, 1993). Texture profile analysis (TPA) was conducted using a TA.XT2 Texture Analyzer (Texture Technologies Corp., Scarsdale, NY) equipped with a $36-\mathrm{mm}$ cylinder probe in triplicate. The cheese was carefully cut into cylinders with $20 \mathrm{~mm}$ height and 20 $\mathrm{mm}$ diameter using a stainless steel cylinder knife and was held at room temperature $\left(20^{\circ} \mathrm{C}\right)$. The recorded TPA parameters were hardness, springiness, gummi- 
Raw cow milk reception

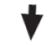

Standardization

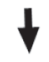

Bactofugation (in two stages)

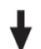

Pasteurization (HTST) $\left(72^{\circ} \mathrm{C} / 15 \mathrm{~s}\right)$

Ultrafiltration (at $50^{\circ} \mathrm{C}$ )

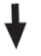

Pasteurization of retentate $\left(78^{\circ} \mathrm{C}, 1 \mathrm{~min}\right)$

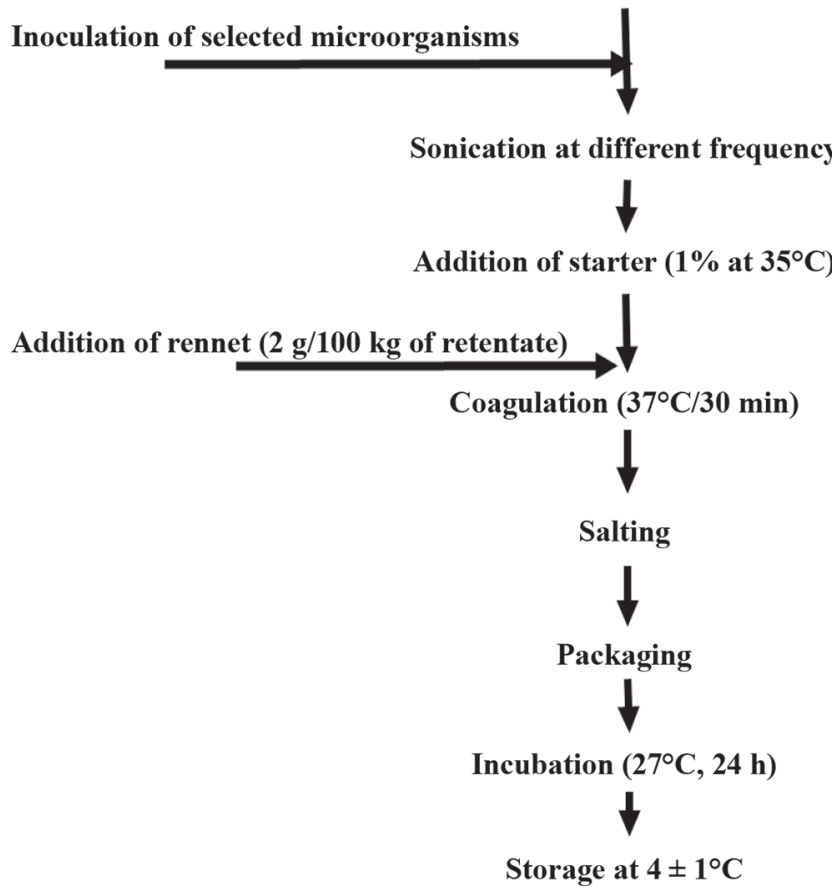

Figure 1. Cheesemaking process using cow milk.

ness, and cohesiveness, measured by the software at $50 \%$ compression with pre-test speed of $1.0 \mathrm{~mm} / \mathrm{s}$ and test speed of $1 \mathrm{~mm} / \mathrm{s}$ (Rashidi et al., 2015).

\section{Sensory Evaluation}

Sensory analysis of UF cheese was evaluated at 15 , 30 , and $60 \mathrm{~d}$ of ripening according to the procedure of Iranian national standard no. 4691 (ISIRI, 1998). Samples for sensory analysis were produced separately from other samples according to the procedure shown in Figure 1 but excluding the inoculation with selected microorganisms. Fifteen panelists were selected and trained to evaluate appearance, texture, flavor, and overall acceptability on a scale from 0 to 5 . Each score for sensorial properties was considered a repetition for statistical analysis.

\section{Statistical Analyses}

All analyses of microbial and physicochemical properties were performed in triplicate, and the results are reported as means \pm standard deviations. To examine the influence of frequency $(20,40$, and $60 \mathrm{kHz})$ and ripening period, all the data were analyzed by multifactor ANOVA using the least significant difference (LSD) test $(P<0.05)$. In addition, comparison of the means was carried out using Duncan's multiple range tests using SPSS statistical software (version 24, IBM Corp., Armonk, NY).

\section{RESULTS AND DISCUSSION}

\section{Microbiological Assay}

Results showing the effect of sonication on the growth of E. coli O157:H7, S. aureus, P. chrysogenum, and $C l$. sporogenes are presented in Figure 2. Inactivation of $E$. coli O157:H7 (a gram-negative bacterium) at 20, 40 and $60 \mathrm{kHz}$ was $4.08,4.17$, and $4.28 \log$ cycles, respectively, whereas the count of E. coli O157:H7 in the control sample increased by $1 \log$ in the first $7 \mathrm{~d}$ of ripening (Figure 2A). The greatest reduction was observed following sonication at $60 \mathrm{kHz}$. The results showed no linear correlation between sonication frequency and inactivation rate of all strains studied To determine the correct model between sonication frequency and inactivation rate of bacteria, fitting parameters such as ultrasound power, initial microbial load, and microbial cell shear strength must be taken into account. Studies conducted by Gao et al. (2014) showed that the log of the inactivation ratio decreased linearly with sonication time, and the rate of inactivation increased (Dvalue decreased) with the increase in sonication power. However, they showed that with an increase in initial microbial numbers, the relationship of survival and rate of decrease was not linear. A study by Sienkiewicz et al. (2017) showed no linear correlation between sonication frequency and inactivation rate of microorganisms, in agreement with our findings. Cameron et al. (2009) showed that applying ultrasound $(20 \mathrm{kHz}, 750 \mathrm{~W})$ for 10 min could decrease an initial microbial load of $1 \times$ $10^{4} \mathrm{cfu} / \mathrm{mL}$ in milk containing $4 \%$ fat and in normal saline to zero. Considering that the inactivation rate of microorganisms by ultrasound depends on parameters such as the viscosity of the medium (Arroyo et al., 2011a) and the initial microbial load (Tsukamoto, 2004; Hunter et al., 2008), a smaller reduction of E. coli 

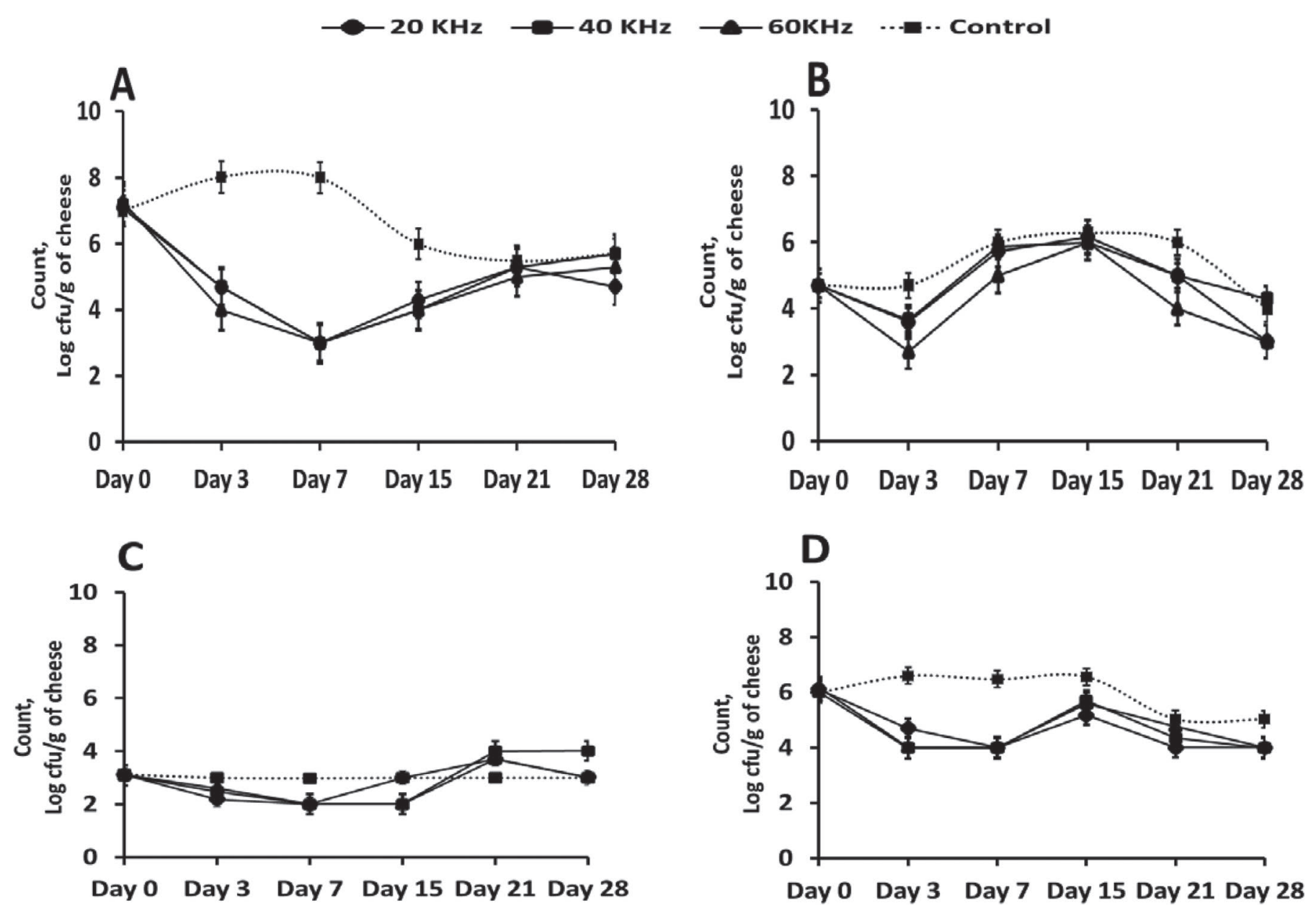

Figure 2. The effect of different ultrasound frequencies (0,20,40, or $60 \mathrm{kHz}, 70 \%$ intensity, $20 \mathrm{~min})$ on the growth of (A) Escherichia coli O157:H7, (B) Staphylococcus aureus, (C) Penicillium chrysogenum, and (D) Clostridium sporogenes in Iranian UF white cheese. Values are mean of at least 3 replicates; error bars indicate standard deviations between means.

O157:H7 compared with that reported previous studies is reasonable.

The greatest inactivation of $S$. aureus (a grampositive bacteria) was detected at $60 \mathrm{kHz}$ and resulted in a $1.95-\log$ decrease after $20 \mathrm{~min}$ (Figure 2B). The inactivation rates of $S$. aureus at 20 and $40 \mathrm{kHz}$ were 1.10 and $1.03 \mathrm{log}$, respectively. Cregenzán-Alberti et al. (2014) reported that the inactivation rate of $E$. coli (0.36 to $1.62 \mathrm{log}$ ) was higher than that of $S$. aureus (0.27 to $1.05 \mathrm{log})$ in sonicated homogenized milk. The results of the present study were similar to the results of Drakopoulou et al. (2009).

The effect of sonication on retentate containing $P$. chrysogenum is illustrated in Figure 2C. Reductions on the 7 th day of ripening at 20,40 , and $60 \mathrm{kHz}$ were $1.11,1.07$, and $1.11 \log$, respectively $(P>0.05)$. To our knowledge, the effect of ultrasound on $P$. chrysogenum has not previously been reported. However, according to Yang et al. (2011), ultrasound alone (at $40 \mathrm{kHz}$ for
10 min) did not reduce the count of Penicillium expansum in peach as whole fruit, and the use of salicylic acid with ultrasound resulted in a greater reduction in P. expansum count. Herceg et al. (2012) studied the effects of high-power ultrasound and plasma gas phase on Aspergillus spp. and Penicillium spp. in pure culture medium. They showed that application of ultrasound alone $(20 \mathrm{kHz}, 42 \mathrm{~W}, 120 \mu \mathrm{m}$ amplitude, for $9 \mathrm{~min}$ at $20^{\circ} \mathrm{C}$ ) could reduce the count of $P$. expansum by 1.26 $\log$, which is in agreement with our results (Figure 2C).

Ultrasound treatment at 20,40, and $60 \mathrm{kHz}$ reduced the count of $\mathrm{Cl}$. sporogenes (Figure 2D) by 2.11, 2.03, and $2.17 \mathrm{log}$, respectively. The initial counts in the 20, 40 , and $60 \mathrm{kHz}$ treatments were $6.11,6.02$, and $6.17 \mathrm{log}$, and decreased to 4.00, 3.99, and $4.00 \mathrm{log}$, respectively, on d 7 of storage. However, counts in the control samples increased from an initial value of 5.99 to $6.47 \mathrm{log}$ on $\mathrm{d}$ 7. The decrease seems to be due to $\mathrm{Cl}$. sporogenes vegetative cells, which are easily destroyed by physical 
treatments such as ultrasound (Talukdar et al., 2017). To the best of our knowledge, the effect of ultrasound on $\mathrm{Cl}$. sporogenes has not yet been reported. Previous studies by Goodenough and Solberg (1972) and Broda (2007) showed that ultrasound alone is not effective in reducing Clostridium spores. Evelyn and Silva (2015) evaluated the effect of ultrasound on enhancing thermal deactivation of $\mathrm{Cl}$. perfringens spores in beef slurry. Their results showed that a combination of thermal shock and ultrasound treatment can increase the reduction rate of spores of this bacterium.

After applying the ultrasound treatments on retentate of milk, the starter culture was added and cheese making was performed according to Figure 1. To investigate the possible effect of ultrasound on starter activity, the starter bacteria were also counted during cheese ripening. Sonication had no significant $(P>$ 0.05 ) effect on starter activity but the effect of time was significant (Figure 3). The count of starter bacteria in all treatments decreased over time, in agreement with the results of Hannon et al. (2006). They reported that the amount of mesophilic and thermophilic starter decreased due to autolysis during cheese ripening.

\section{Physicochemical Characteristics}

The mean data for $\mathrm{pH}$, titratable acidity, DM, fat in $\mathrm{DM}$, salt in moisture, and protein in UF white cheese samples during the ripening period (evaluated at 1, 15, 30,45 , and $60 \mathrm{~d}$ ) under the different ultrasound treatments $(20,40$, and $60 \mathrm{kHz})$ are presented in Table 1. The $\mathrm{pH}$ values of all sonicated samples were lower than that of the control at the end of the storage period. The most important factor related to $\mathrm{pH}$ change during ripening of cheese is the activity of lactic acid bacteria (Hayaloglu et al., 2005). Bermúdez-Aguirre et al. (2009) reported that ultrasound pretreatment with different amplitudes and times significantly $(P<0.05)$ decreased the $\mathrm{pH}$ of milk, which is similar to the findings of the present study. However, some researchers observed that the $\mathrm{pH}$ of the ultrasound-treated milk $(20 \mathrm{kHz})$ and untreated control samples were not statistically different (Jambrak et al., 2009; Yanjun et al., 2014).

Our results showed that ultrasonic pretreatment improved cheese acidity at the end of ripening period (Table 1). Compared with the control, acidity was higher in all sonicated samples on d 60 of ripening, and there was no linear relationship between sonication frequency and acidity, consistent with the results of Marchesini et al. (2012). Increasing acidity due to ultrasound can be attributed to hydrolysis of triglycerides and the consequent increase of FFA (Uluko et al., 2015).

The ANOVA results showed that the effects of sonication and time on the DM content of the cheese were significant $(P<0.05)$ but the interaction between time and treatment was not $(P>0.05)$. The DM content of all treatments decreased slightly during ripening, which could be due to the increase of solubility and the leaching of some cheese compounds into whey. These results are in agreement with the results of Zhao et al. (2014), who reported that ultrasound $(20 \mathrm{kHz}, 60$ min) slightly increased solubility of whey proteins, calcium, and phosphorus, which can be separated from the cheese matrix during ripening and consequently reduce DM. On the other hand, ultrasonic pretreatment can increase the water-holding capacity, resulting in an increase in moisture content of cheese and a decrease in the amount of DM.

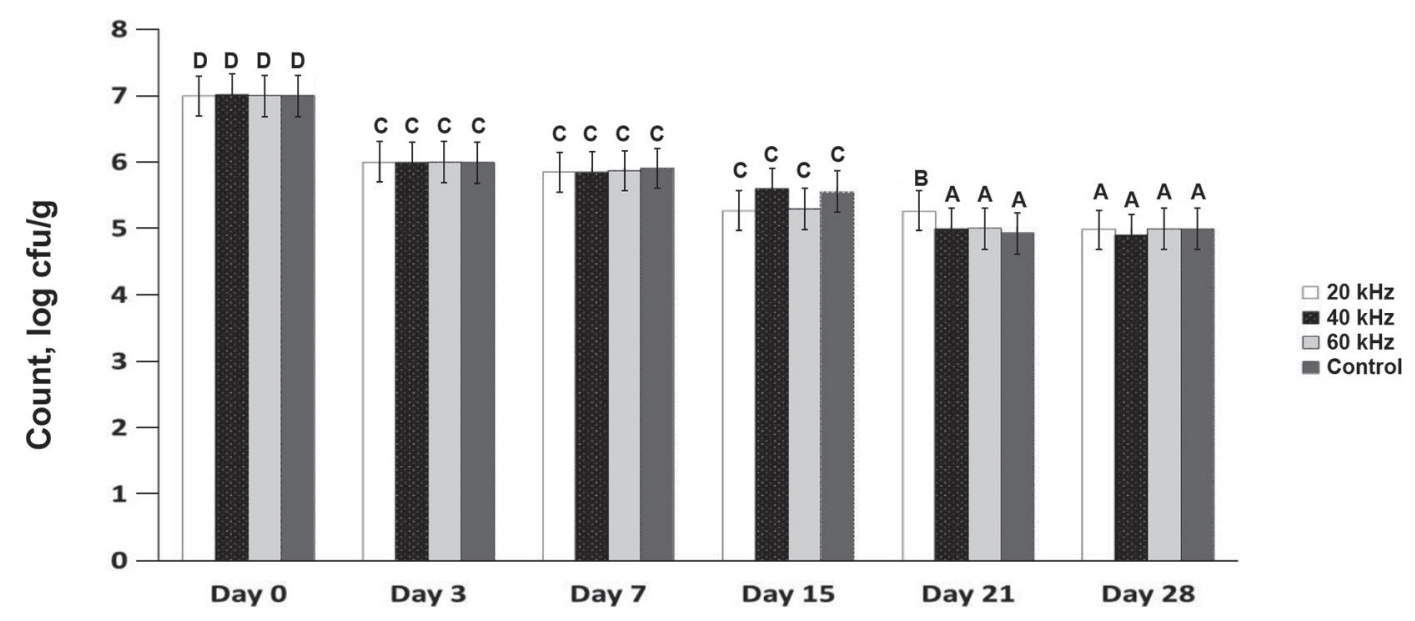

Figure 3. Effect of different ultrasound frequencies $(0,20,40$, or $60 \mathrm{kHz})$ as pretreatment on cheese starter activity during ripening period. Values are mean of at least 3 replicates; error bars indicate standard deviation between means. Different uppercase letters $(\mathrm{A}-\mathrm{D})$ show differences between ripening times within the same sample $(P<0.05)$. No differences were observed between treatments at the same ripening time. 
The effect of sonication on the content of fat in DM of cheese during ripening (Table 1$)$ was not significant $(P$ $>0.05)$. Cameron et al. (2009) reported that the sonication of raw milk and pasteurized milk could reduce the size of fat globules and change their surface area, resulting in better milk fat extraction by the MilkoScan and could eventually lead to an increase in milk fat content. In our study, milk was homogenized before sonication in the production line and the amount of fat was measured by the Van Gulik method. The results obtained by Sanchez et al. (2001a) and Bermúdez-Aguirre and Barbosa-Cánovas (2008) showed that, similar to our results, ultrasound treatment had no significant effect on milk or cheese fat contents.
Sonication did not significantly $(P>0.05)$ affect protein content of cheese samples during $60 \mathrm{~d}$ of storage (Table 1). However, the protein content of all treatments decreased during ripening. Reduction in protein content can be due to transfer of soluble compounds from cheese curd to whey during storage. A slight decrease in cheese protein content during ripening was reported by Hayaloglu et al. (2005). Sánchez et al. (2001b) also reported that sonication $(30 \mathrm{kHz}$ and $300 \mathrm{~W})$ did not have a significant effect on protein content of Mahon cheese. Studies conducted by Cameron et al. (2009) and Marchesini et al. (2012) showed that ultrasound pretreatment had no effect on the protein content of milk measured by Kjeldahl method, but that measured

Table 1. Effect of different frequencies of ultrasound pretreatment (at 0, 20,40, or $60 \mathrm{kHz}$ ) on $\mathrm{pH}$ and chemical composition of Iranian UF white cheese during ripening ${ }^{1}$

\begin{tabular}{|c|c|c|c|c|}
\hline \multirow{2}{*}{$\begin{array}{l}\text { Composition and } \\
\text { ripening stage }\end{array}$} & \multicolumn{4}{|c|}{ Treatment } \\
\hline & Control & $20 \mathrm{kHz}$ & $40 \mathrm{kHz}$ & $60 \mathrm{kHz}$ \\
\hline \multicolumn{5}{|l|}{$\mathrm{pH}$} \\
\hline d 1 & $4.70 \pm 0.000^{\mathrm{B}, \mathrm{b}}$ & $4.73 \pm 0.010^{\mathrm{C}, \mathrm{c}}$ & $4.71 \pm 0.012^{\mathrm{B}, \mathrm{b}}$ & $4.68 \pm 0.012^{\mathrm{B}, \mathrm{a}}$ \\
\hline d 15 & $4.80 \pm 0.01^{\mathrm{C}, \mathrm{d}}$ & $4.67 \pm 0.015^{\mathrm{B}, \mathrm{a}}$ & $4.76 \pm 0.010^{\mathrm{C}, \mathrm{c}}$ & $4.72 \pm 0.006^{\mathrm{B}, \mathrm{b}}$ \\
\hline d 30 & $4.52 \pm 0.01^{\mathrm{A}, \mathrm{b}}$ & $4.48 \pm 0.006^{\mathrm{A}, \mathrm{a}}$ & $4.49 \pm 0.006^{\mathrm{A}, \mathrm{a}}$ & $4.54 \pm 0.01^{\mathrm{A}, \mathrm{c}}$ \\
\hline d 45 & $4.79 \pm 0.01^{\mathrm{C}, \mathrm{c}}$ & $4.74 \pm 0.006^{\mathrm{C}, \mathrm{a}}$ & $4.77 \pm 0.010^{\mathrm{C}, \mathrm{b}}$ & $4.75 \pm 0.006^{\mathrm{C}, \mathrm{a}}$ \\
\hline d 60 & $4.85 \pm 0.006^{\mathrm{D}, \mathrm{c}}$ & $4.79 \pm 0.012^{\mathrm{D}, \mathrm{b}}$ & $4.70 \pm 0.015^{\mathrm{B}, \mathrm{a}}$ & $4.80 \pm 0.012^{\mathrm{D}, \mathrm{b}}$ \\
\hline \multicolumn{5}{|l|}{ Acidity } \\
\hline d 1 & $1.69 \pm 0.01^{\mathrm{C}, \mathrm{c}}$ & $1.46 \pm 0.01^{\mathrm{A}, \mathrm{a}}$ & $1.61 \pm 0.015^{\mathrm{A}, \mathrm{b}}$ & $1.75 \pm 0.01^{\mathrm{B}, \mathrm{d}}$ \\
\hline d 15 & $1.71 \pm 0.002^{\mathrm{D}, \mathrm{a}}$ & $1.70 \pm 0.022^{\mathrm{C}, \mathrm{a}}$ & $1.72 \pm 0.022^{\mathrm{B}, \mathrm{a}}$ & $1.70 \pm 0.041^{\mathrm{B}, \mathrm{a}}$ \\
\hline d 30 & $1.72 \pm 0.023^{\mathrm{D}, \mathrm{a}}$ & $1.75 \pm 0.008^{\mathrm{D}, \mathrm{b}}$ & $1.80 \pm 0.014^{\mathrm{C}, \mathrm{c}}$ & $1.73 \pm 0.003^{\mathrm{B}, \mathrm{a}}$ \\
\hline d 45 & $1.60 \pm 0.006^{\mathrm{A}, \mathrm{a}}$ & $1.77 \pm 0.012^{\mathrm{D}, \mathrm{d}}$ & $1.70 \pm 0.021^{\mathrm{B}, \mathrm{c}}$ & $1.65 \pm 0.009^{\mathrm{A}, \mathrm{b}}$ \\
\hline d 60 & $1.65 \pm 0.029^{\mathrm{A}, \mathrm{b}}$ & $1.78 \pm 0.052^{\mathrm{B}, \mathrm{d}}$ & $1.74 \pm 0.028^{\mathrm{B}, \mathrm{c}}$ & $1.66 \pm 0.014^{\mathrm{A}, \mathrm{b}}$ \\
\hline \multicolumn{5}{|r|}{$1.00+0.014$} \\
\hline d 1 & $34.30 \pm 0.43^{\mathrm{B}, \mathrm{a}}$ & $35.55 \pm 0.48^{\mathrm{B}, \mathrm{c}}$ & $35.05 \pm 0.16^{\mathrm{C}, \mathrm{bc}}$ & $34.61 \pm 0.35^{\mathrm{B}, \mathrm{ab}}$ \\
\hline d 15 & $33.11 \pm 0.07^{\mathrm{A}, \mathrm{a}}$ & $35.27 \pm 1.17^{\mathrm{B}, \mathrm{b}}$ & $34.85 \pm 0.61^{\mathrm{C}, \mathrm{b}}$ & $34.32 \pm 0.55^{\mathrm{AB}, \mathrm{ab}}$ \\
\hline d 30 & $33.08 \pm 0.50^{\mathrm{A}, \mathrm{a}}$ & $34.77 \pm 0.58^{\mathrm{B}, \mathrm{b}}$ & $34.58 \pm 0.30^{\mathrm{C}, \mathrm{b}}$ & $33.74 \pm 0.30^{\mathrm{AB}, \mathrm{a}}$ \\
\hline d 45 & $32.46 \pm 0.73^{\mathrm{A}, \mathrm{a}}$ & $33.53 \pm 0.29^{\mathrm{A}, \mathrm{a}}$ & $33.61 \pm 0.42^{\mathrm{B}, \mathrm{a}}$ & $33.37 \pm 1.16^{\mathrm{AB}, \mathrm{a}}$ \\
\hline d 60 & $32.21 \pm 0.47^{\mathrm{A}, \mathrm{ab}}$ & $32.64 \pm 0.31^{\mathrm{A}, \mathrm{ab}}$ & $31.76 \pm 0.64^{\mathrm{A}, \mathrm{a}}$ & $32.97 \pm 0.79^{\mathrm{A}, \mathrm{b}}$ \\
\hline \multicolumn{5}{|l|}{ Fat in DM, \% } \\
\hline d 1 & $43.25 \pm 1.35^{\mathrm{A}, \mathrm{a}}$ & $42.20 \pm 1.57^{\mathrm{A}, \mathrm{a}}$ & $42.32 \pm 2.14^{\mathrm{A}, \mathrm{a}}$ & $42.80 \pm 1.94^{\mathrm{A}, \mathrm{a}}$ \\
\hline d 15 & $43.79 \pm 0.54^{\mathrm{A}, \mathrm{a}}$ & $42.53 \pm 0.45^{\mathrm{A}, \mathrm{a}}$ & $43.57 \pm 1.73^{\mathrm{A}, \mathrm{a}}$ & $42.80 \pm 2.16^{\mathrm{A}, \mathrm{a}}$ \\
\hline d 30 & $43.32 \pm 1.37^{\mathrm{A}, \mathrm{a}}$ & $42.83 \pm 3.01^{\mathrm{A}, \mathrm{a}}$ & $42.80 \pm 0.66^{\mathrm{A}, \mathrm{a}}$ & $43.67 \pm 1.07^{\mathrm{A}, \mathrm{a}}$ \\
\hline d 45 & $42.62 \pm 2.38^{\mathrm{A}, \mathrm{a}}$ & $43.76 \pm 2.64^{\mathrm{A}, \mathrm{a}}$ & $43.13 \pm 1.07^{\mathrm{A}, \mathrm{a}}$ & $43.09 \pm 2.30^{\mathrm{A}, \mathrm{a}}$ \\
\hline d 60 & $39.95 \pm 1.75^{\mathrm{A}, \mathrm{a}}$ & $41.86 \pm 1.65^{\mathrm{A}, \mathrm{a}}$ & $43.56 \pm 0.48^{\mathrm{A}, \mathrm{a}}$ & $42.56 \pm 0.50^{\mathrm{A}, \mathrm{a}}$ \\
\hline \multicolumn{5}{|l|}{ Salt in moisture, $\%$} \\
\hline d 1 & $2.88 \pm 0.08^{\mathrm{C}, \mathrm{c}}$ & $2.15 \pm 0.03^{\mathrm{C}, \mathrm{b}}$ & $2.02 \pm 0.04^{\mathrm{BC}, \mathrm{a}}$ & $2.16 \pm 0.03^{\mathrm{C}, \mathrm{b}}$ \\
\hline d 15 & $1.91 \pm 0.04^{\mathrm{A}, \mathrm{a}}$ & $1.93 \pm 0.06^{\mathrm{AB}, \mathrm{a}}$ & $1.90 \pm 0.05^{\mathrm{A}, \mathrm{a}}$ & $1.89 \pm 0.02^{\mathrm{A}, \mathrm{a}}$ \\
\hline d 30 & $2.05 \pm 0.07^{\mathrm{B}, \mathrm{ab}}$ & $2.18 \pm 0.06^{\mathrm{C}, \mathrm{c}}$ & $2.13 \pm 0.02^{\mathrm{D}, \mathrm{bc}}$ & $2.02 \pm 0.05^{\mathrm{B}, \mathrm{a}}$ \\
\hline d 45 & $2.13 \pm 0.04^{\mathrm{B}, \mathrm{b}}$ & $1.98 \pm 0.05^{\mathrm{B}, \mathrm{a}}$ & $1.99 \pm 0.03^{\mathrm{B}, \mathrm{a}}$ & $2.13 \pm 0.04^{\mathrm{C}, \mathrm{b}}$ \\
\hline d 60 & $1.94 \pm 0.01^{\mathrm{A}, \mathrm{b}}$ & $1.89 \pm 0.02^{\mathrm{A}, \mathrm{a}}$ & $2.06 \pm 0.01^{\mathrm{C}, \mathrm{c}}$ & $2.13 \pm 0.02^{\mathrm{C}, \mathrm{d}}$ \\
\hline \multicolumn{5}{|l|}{ Protein, \% } \\
\hline d 1 & $13.95 \pm 0.100^{\mathrm{B}, \mathrm{a}}$ & $13.96 \pm 0.0105^{\mathrm{B}, \mathrm{a}}$ & $13.95 \pm 0.086^{\mathrm{B}, \mathrm{a}}$ & $13.90 \pm 0.07^{\mathrm{C}, \mathrm{a}}$ \\
\hline d 15 & $13.89 \pm 0.085^{\mathrm{B}, \mathrm{a}}$ & $13.92 \pm 0.12^{\mathrm{B}, \mathrm{a}}$ & $13.94 \pm 0.08^{\mathrm{B}, \mathrm{a}}$ & $13.86 \pm 0.06^{\mathrm{C}, \mathrm{a}}$ \\
\hline d 30 & $13.87 \pm 0.100^{\mathrm{B}, \mathrm{a}}$ & $13.88 \pm 0.08^{\mathrm{B}, \mathrm{a}}$ & $13.88 \pm 0.11^{\mathrm{B}, \mathrm{a}}$ & $13.89 \pm 0.07^{\mathrm{C}, \mathrm{a}}$ \\
\hline d 45 & $13.52 \pm 0.12^{\mathrm{A}, \mathrm{a}}$ & $13.49 \pm 0.07^{\mathrm{A}, \mathrm{a}}$ & $13.51 \pm 0.08^{\mathrm{A}, \mathrm{a}}$ & $13.50 \pm 0.05^{\mathrm{B}, \mathrm{a}}$ \\
\hline d 60 & $13.35 \pm 0.108^{\mathrm{A}, \mathrm{a}}$ & $13.34 \pm 0.12^{\mathrm{A}, \mathrm{a}}$ & $13.38 \pm 0.100^{\mathrm{A}, \mathrm{a}}$ & $13.37 \pm 0.07^{\mathrm{A}, \mathrm{a}}$ \\
\hline
\end{tabular}


using a MilkoScan device (Foss, Hillerød, Denmark) showed a slight increase. The results of our study are in agreement with the findings of the Bermúdez-Aguirre and Barbosa-Cánovas (2008) and Zhao et al. (2014).

\section{Total FFA}

Lipolysis is one of the most important biochemical changes that occur during cheese ripening. The FFA released during lipolysis, along with volatile compounds and proteolytic products, directly contribute to cheese taste (McSweeney and Sousa, 2000). The profile of short- and medium-chain FFA has been suggested as an indicator for determining the lipolysis of the cheese during ripening (Woo et al., 1984). The lipolytic agents in cheese are enzymes present in milk (milk lipase), rennet (pregastric esterase), and milk microflora (Fox et al., 1993; Collins et al., 2003).

The effects of different sonication frequencies on total FFA percentage are presented in Figure 4. The lipolysis index of all samples increased during ripening. These data are in good agreement with findings reported by Karami (2017). The highest rate of lipolysis (7.44\%) at the end of ripening period was achieved with sonication at $60 \mathrm{kHz}$, and the lowest rate $(6.80 \%)$ was reported for the control sample. Reducing fat globules and increasing surface area by ultrasound seems to be the most important factor in increasing the rate of lipolysis. Sanchez et al. (2001a) evaluated the effect of sonication on Mahon cheese lipolysis. The results showed that the intensity of lipolysis in sonicated samples was higher than in those without treatment, which is similar to our findings.

\section{Nitrogen Fractions}

Data on nitrogen fractions of cheese samples are given in Table 2 . Sonication significantly $(P<0.05)$ increased the amount of WSN and NPN as a percentage of TN of cheese samples during ripening. The WSN/ TN of control group varied between 3.53 and $8.29 \%$ during ripening. At the end of the storage period, the WSN values in samples sonicated at 20,40 , and 60 $\mathrm{kHz}$ were $10.57,10.54$, and $10.62 \%$, respectively $(P>$ $0.05)$. These results indicate that sonication can accelerate proteolytic activity. The increase in the WSN fraction of the samples could be due to the increase in solubility of whey proteins by ultrasound. Chandrapala et al. (2012) showed that sonication of milk $(20 \mathrm{kHz}$, over different times) increased the solubility of whey proteins by breaking whey casein-protein linkages. However, acoustic brining of Mahon cheese $(30 \mathrm{kHz}$ and $300 \mathrm{~W}$ ) did not have a significant effect on WSN but did increase the amount of free amino acids (Sanchez et al., 2001b).

Analysis of variance of the NPN data showed that the amount of NPN in all treatments increased with storage time. The increase in the control sample was $1.7 \%$, and increases in samples treated at 20,40, and $60 \mathrm{kHz}$ were $3.84,4.11$, and $4.51 \%$, respectively. An increase in NPN, which mainly consists of short peptides of 2 to 20 units and free AA, during ripening was also reported by Hesari et al. (2006) and Karami et al. (2009). The main reason for the increase of these compounds is the activity of lactic acid bacteria and some enzymes present in the cheese (Tejada et al., 2008). There is no published information on the effect of ultrasound on

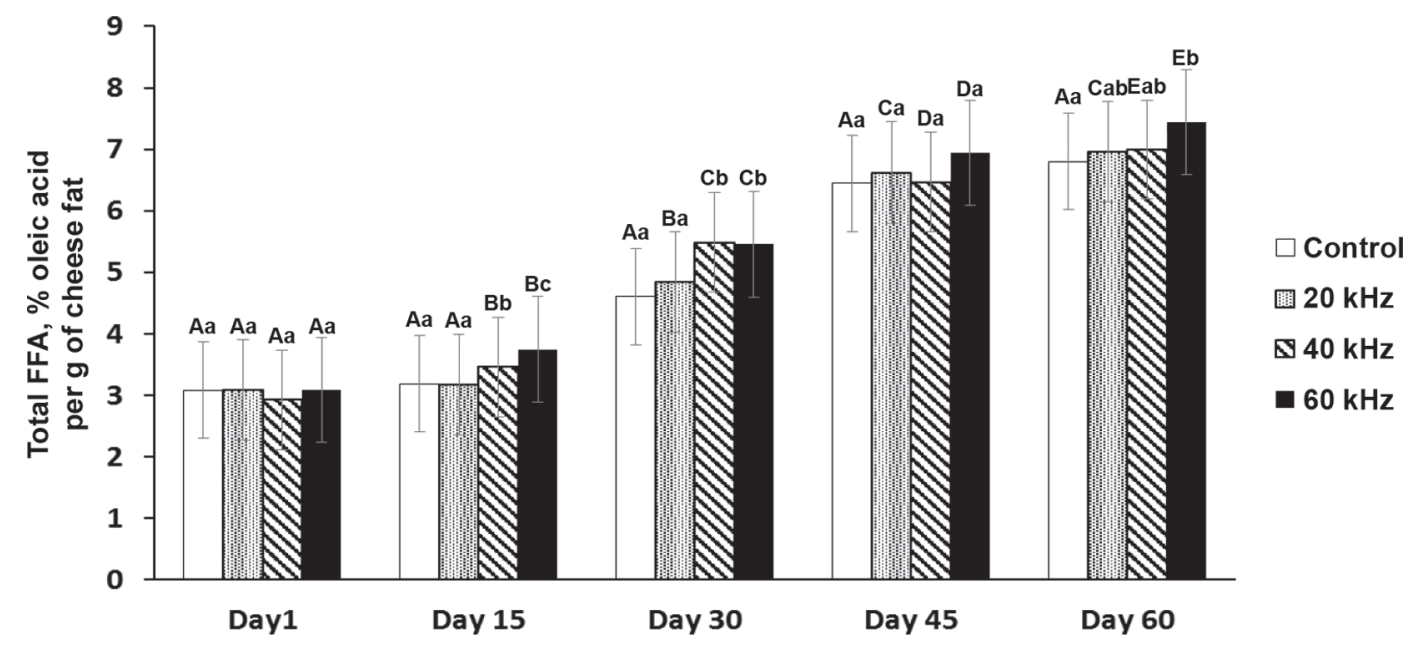

Figure 4. Effect of different ultrasound frequencies (0, 20, 40, or $60 \mathrm{kHz}$ ) on free fatty acid (FFA) level (expressed as total FFA, \% oleic acid per gram of cheese fat) during the ripening period. Values are mean of at least 3 replicates; error bars indicate standard deviation between means. Different lowercase letters $(\mathrm{a}-\mathrm{c})$ show differences between treatments within the same ripening time; different uppercase letters (A-E) show differences between ripening times within the same sample $(P<0.05)$. 
Table 2. The effect of different frequencies of ultrasound pretreatment (at $0,20,40$, or $60 \mathrm{kHz}$ ) on nitrogen fractions in Iranian UF white cheese during ripening ${ }^{1}$

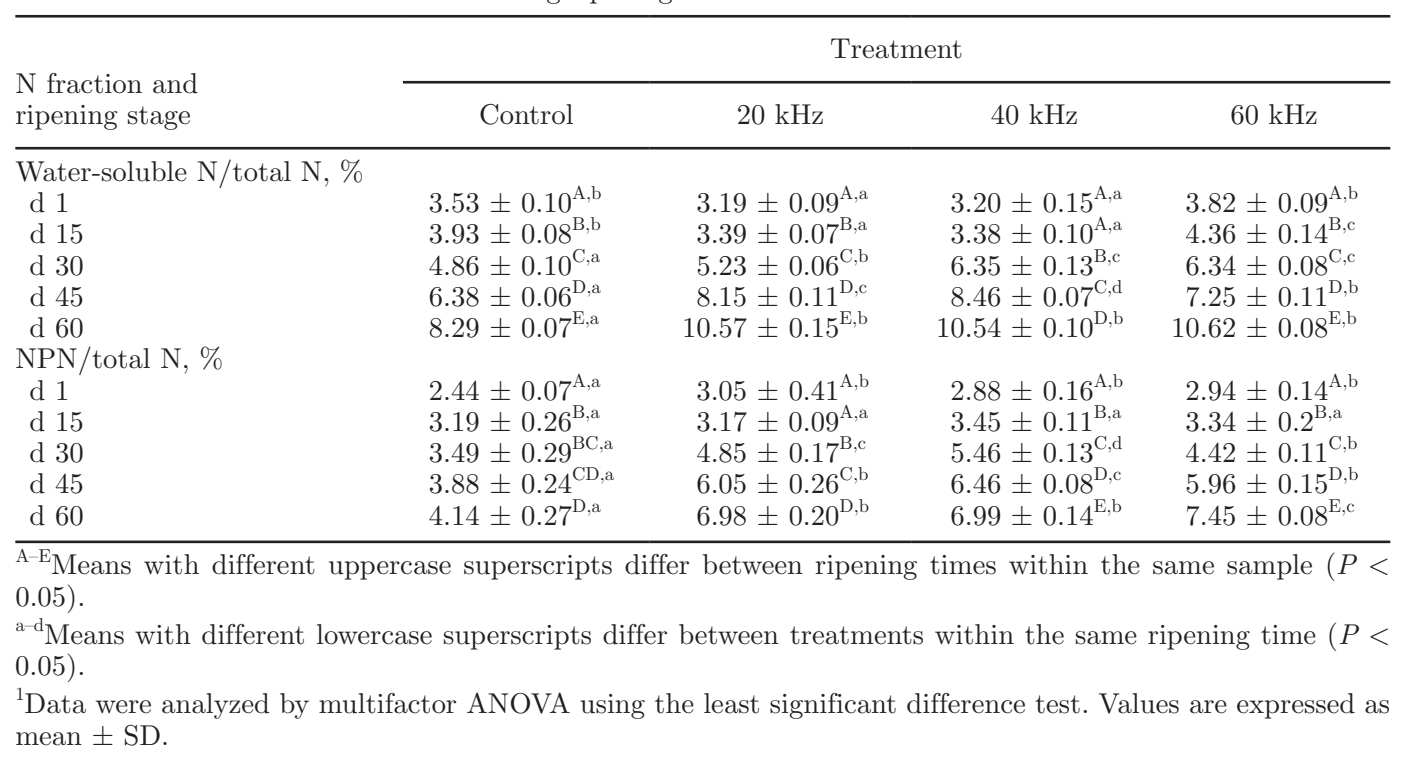

the amount of NPN during ripening of cheese. Sanchez et al. (2001b) reported that sonication of Mahon cheese caused an increase in free AA, although ultrasound had no significant effect on NPN. Marchesini et al. (2012) showed that ultrasound treatment could significantly increase the amount of urea in milk, which could explain the increase in NPN of the cheese during ripening.

\section{Texture Profiles}

Changes in texture profiles of UF white cheese made with sonicated milk are presented in Table 3 . The ANOVA results revealed that sonication at different frequencies had no significant $(P>0.05)$ effect on hardness of cheese samples, but the effect of ripening time and the interaction between time and sonication frequency were significant $(P<0.05)$. Hardness of all samples increased during the first $30 \mathrm{~d}$ because of a decrease in moisture content of cheese samples, and then decreased until $60 \mathrm{~d}$ due to progressive proteolysis. The highest hardness was detected on d 30 in samples treated at 20 and $40 \mathrm{kHz}$ and the lowest hardness was detected at the end of storage, with no significant difference $(P$ $>0.05)$ between samples. Tunick et al. (1991) demonstrated that cheese tends to become softer due to the proteolytic breakdown of casein. Villamiel et al. (1999) studied the effect of sonication on the proteolytic activity of enzymes involved in milk curdling. They noted that ultrasound speeds up the hardening of curd and leads to greater firmness in the final product, which is in agreement with the results of the present study.
Sonication had no significant $(P>0.05)$ effect on cohesiveness or springiness of cheese samples throughout $60 \mathrm{~d}$, which may be because the fat in DM content did not change in cheese samples during ripening (Table 1). Eroglu et al. (2016) demonstrated that cohesiveness and springiness of Kashar cheese did not change significantly during $60 \mathrm{~d}$ of ripening. Ahmed et al. (2016) revealed that cohesiveness and springiness of UF white cheese did not change during 4 wk of storage, which is similar to the findings of the present study.

Gumminess is defined as the energy needed to disintegrate a semisolid food until it is ready for swallowing, and it is calculated by multiplying the hardness and cohesiveness values of the sample (Gunasekaran and Ak, 2002); therefore, factors affecting the hardness and cohesiveness of the sample also affect gumminess. Similar to the hardness of cheese samples, gumminess of all samples increased during the first $30 \mathrm{~d}$ and then decreased until $60 \mathrm{~d}$. The highest gumminess was detected in sonicated samples on d 30, and the lowest hardness was observed at the end of storage, without any difference $(P>0.05)$ between samples.

Zhao et al. (2014) investigated the effect of ultrasound pretreatment for different times on rennet-induced coagulation properties of goat milk. Their results demonstrated that sonication significantly $(P<0.05)$ increased firmness, cohesiveness, and springiness of goat milk cheese, which seems to contradict the results of the present study, likely because of the difference in sonication parameters, length of storage, and type of cheese. They did not investigate the effect of ripening 
period, which has an important role in textural profile of cheese.

\section{Sensory Properties}

Ultrasonication had a significant $(P<0.05)$ effect on the organoleptic properties of cheese samples (Table 4). Sensory scores increased during storage due to the progression of proteolysis and lipolysis, which is in agreement with the results of Karami (2017) and Georgala et al. (2005) but contradicts the results of Yasar and Guzeler (2011). Ultrasound treatment significantly $(P<$ $0.05)$ improved the color and appearance of UF cheese. The lowest color and appearance scores were obtained for the control sample, and there were no significant $(P>0.05)$ differences among the different sonication treatments. Bermúdez-Aguirre et al. (2009) showed that sonication modifies the color of milk and will affect the final color of dairy products such as cheese or yogurt. These results are in agreement with the results of the present study. We detected no difference $(P<$ $0.05)$ between the mean texture scores of the control and the sample sonicated at $60 \mathrm{kHz}$, but the highest texture scores were found in samples sonicated at 20 and $40 \mathrm{kHz}$. Ultrasound treatment increased flavor and taste scores due to greater lipolysis and proteolysis compared with the control sample. In terms of overall acceptance, the highest scores were obtained for UF cheese sonicated at $60 \mathrm{kHz}$ and the lowest scores for the untreated control sample. These results are in agreement with Sanchez et al. (2001a).

\section{CONCLUSIONS}

Sonication significantly reduced the growth of $E$. coli O157:H7, S. aureus, P. chrysogenum, and Cl. sporogenes in cheese. The highest inactivation rate of $E$. coli $\mathrm{O} 157: \mathrm{H} 7$ and $S$. aureus was observed in samples sonicated at $60 \mathrm{kHz}$. However, no significant differences were observed between different sonication frequencies in deactivation of $P$. chrysogenum or $C l$. sporogenes. The $\mathrm{pH}$ values of all treated samples at the end of storage were lower than that of control, and the highest acidity was found in the sample sonicated at $20 \mathrm{kHz}$. The DM contents of all samples decreased slightly over $60 \mathrm{~d}$ of ripening. The greatest reduction in DM was found in the sample sonicated at $40 \mathrm{kHz}$, and smallest reduction was found in the control sample and that

Table 3. The effect of different frequencies of ultrasound pretreatment (at $0,20,40$, or $60 \mathrm{kHz}$ ) on texture profile analysis of Iranian UF white cheese during ripening ${ }^{1}$

\begin{tabular}{|c|c|c|c|c|}
\hline \multirow{2}{*}{$\begin{array}{l}\text { Texture variable and } \\
\text { ripening stage }\end{array}$} & \multicolumn{4}{|c|}{ Treatment } \\
\hline & Control & $20 \mathrm{kHz}$ & $40 \mathrm{kHz}$ & $60 \mathrm{kHz}$ \\
\hline \multicolumn{5}{|l|}{ Hardness, $\mathrm{g}$} \\
\hline d 1 & $233.33 \pm 30.53^{\mathrm{A}}$ & $247.00 \pm 15.52^{\mathrm{B}}$ & $237.00 \pm 14.42^{\mathrm{B}}$ & $234.33 \pm 30.23^{\mathrm{A}}$ \\
\hline d 15 & $288.00 \pm 16.09^{\mathrm{B}}$ & $301.67 \pm 15.17^{\mathrm{C}}$ & $294.00 \pm 30.51^{\mathrm{C}}$ & $291.00 \pm 12.12^{\mathrm{B}}$ \\
\hline d 30 & $286.67 \pm 18.34^{\mathrm{B}}$ & $295.00 \pm 20.66^{\mathrm{C}}$ & $292.33 \pm 12.06^{\mathrm{C}}$ & $291.66 \pm 17.03^{\mathrm{B}}$ \\
\hline d 45 & $259.00 \pm 19.00^{\mathrm{AB}}$ & $248.33 \pm 20.03^{\mathrm{B}}$ & $238.67 \pm 18.50^{\mathrm{B}}$ & $237.00 \pm 19.67^{\mathrm{A}}$ \\
\hline d 60 & $218.67 \pm 30.00^{\mathrm{A}}$ & $197.33 \pm 22.50^{\mathrm{A}}$ & $191.00 \pm 24.00^{\mathrm{A}}$ & $196.33 \pm 30.75^{\mathrm{A}}$ \\
\hline \multicolumn{5}{|l|}{ Cohesiveness } \\
\hline d 1 & $0.20 \pm 0.05^{\mathrm{A}}$ & $0.20 \pm 0.05^{\mathrm{A}}$ & $0.21 \pm 0.02^{\mathrm{A}}$ & $0.20 \pm 0.01^{\mathrm{A}}$ \\
\hline d 15 & $0.22 \pm 0.04^{\mathrm{A}}$ & $0.21 \pm 0.04^{\mathrm{A}}$ & $0.22 \pm 0.04^{\mathrm{A}}$ & $0.22 \pm 0.03^{\mathrm{A}}$ \\
\hline d 30 & $0.23 \pm 0.015^{\mathrm{A}}$ & $0.24 \pm 0.025^{\mathrm{A}}$ & $0.24 \pm 0.04^{\mathrm{A}}$ & $0.25 \pm 0.03^{\mathrm{A}}$ \\
\hline d 45 & $0.24 \pm 0.06^{\mathrm{A}}$ & $0.23 \pm 0.03^{\mathrm{A}}$ & $0.24 \pm 0.05^{\mathrm{A}}$ & $0.26 \pm 0.02^{\mathrm{A}}$ \\
\hline d 60 & $0.26 \pm 0.05^{\mathrm{A}}$ & $0.28 \pm 0.06^{\mathrm{A}}$ & $0.26 \pm 0.05^{\mathrm{A}}$ & $0.25 \pm 0.04^{\mathrm{A}}$ \\
\hline \multicolumn{5}{|l|}{ Springiness, mm } \\
\hline d 1 & $4.56 \pm 0.41^{\mathrm{A}}$ & $4.57 \pm 0.35^{\mathrm{A}}$ & $4.72 \pm 0.25^{\mathrm{A}}$ & $4.68 \pm 0.43^{\mathrm{A}}$ \\
\hline d 15 & $4.73 \pm 0.60^{\mathrm{A}}$ & $4.72 \pm 0.65^{\mathrm{A}}$ & $4.66 \pm 0.67^{\mathrm{A}}$ & $4.69 \pm 0.20^{\mathrm{A}}$ \\
\hline d 30 & $4.69 \pm 0.38^{\mathrm{A}}$ & $4.78 \pm 0.41^{\mathrm{A}}$ & $4.72 \pm 0.46^{\mathrm{A}}$ & $4.79 \pm 0.33^{\mathrm{A}}$ \\
\hline d 45 & $5.07 \pm 0.55^{\mathrm{A}}$ & $4.99 \pm 0.60^{\mathrm{A}}$ & $5.02 \pm 0.60^{\mathrm{A}}$ & $4.92 \pm 0.46^{\mathrm{A}}$ \\
\hline d 60 & $4.54 \pm 0.48^{\mathrm{A}}$ & $4.53 \pm 0.49^{\mathrm{A}}$ & $4.55 \pm 0.49^{\mathrm{A}}$ & $4.50 \pm 0.50^{\mathrm{A}}$ \\
\hline \multicolumn{5}{|l|}{ Gumminess, $\mathrm{g}$} \\
\hline d 1 & $46.79 \pm 17.16^{\mathrm{A}}$ & $49.62 \pm 9.42^{\mathrm{A}}$ & $49.81 \pm 5.70^{\mathrm{A}}$ & $46.73 \pm 4.94^{\mathrm{A}}$ \\
\hline d 15 & $62.88 \pm 16.37^{\mathrm{A}}$ & $64.16 \pm 9.32^{\mathrm{AB}}$ & $64.66 \pm 12.28^{\mathrm{A}}$ & $63.78 \pm 6.09^{\mathrm{AB}}$ \\
\hline d 30 & $66.73 \pm 2.40^{\AA}$ & $72.02 \pm 11.79^{\mathrm{B}}$ & $70.49 \pm 15.75^{\mathrm{A}}$ & $72.15 \pm 12.22^{\mathrm{B}}$ \\
\hline d 45 & $62.90 \pm 20.20^{\mathrm{A}}$ & $58.100 \pm 10.03^{\mathrm{AB}}$ & $56.70 \pm 13.77^{\mathrm{A}}$ & $60.50 \pm 1.03^{\mathrm{AB}}$ \\
\hline d 60 & $58.12 \pm 15.20^{\mathrm{A}}$ & $54.38 \pm 7.00^{\mathrm{AB}}$ & $49.02 \pm 6.13^{\mathrm{A}}$ & $50.27 \pm 14.03^{\mathrm{A}}$ \\
\hline
\end{tabular}


Table 4. The effect of different frequencies of ultrasound pretreatment (at $0,20,40$, or $60 \mathrm{kHz}$ ) on organoleptic properties of Iranian UF cheeses during ripening ${ }^{1}$

\begin{tabular}{|c|c|c|c|c|}
\hline \multirow{2}{*}{$\begin{array}{l}\text { Organoleptic property } \\
\text { and ripening stage }\end{array}$} & \multicolumn{4}{|c|}{ Treatment } \\
\hline & Control & $20 \mathrm{kHz}$ & $40 \mathrm{kHz}$ & $60 \mathrm{kHz}$ \\
\hline \multicolumn{5}{|l|}{ Color and appearance } \\
\hline d 15 & $4.29 \pm 0.30^{\mathrm{A}, \mathrm{a}}$ & $4.85 \pm 0.41^{\mathrm{A}, \mathrm{b}}$ & $4.77 \pm 0.27^{\mathrm{A}, \mathrm{b}}$ & $4.80 \pm 0.20^{\mathrm{A}, \mathrm{b}}$ \\
\hline d 30 & $4.20 \pm 0.40^{\mathrm{A}, \mathrm{a}}$ & $4.67 \pm 0.32^{\mathrm{A}, \mathrm{b}}$ & $4.81 \pm 0.31^{\mathrm{A}, \mathrm{b}}$ & $4.67 \pm 0.52^{\mathrm{A}, \mathrm{b}}$ \\
\hline d 60 & $4.35 \pm 0.25^{\mathrm{A}, \mathrm{a}}$ & $4.78 \pm 0.21^{\mathrm{A}, \mathrm{b}}$ & $4.80 \pm 0.22^{\mathrm{A}, \mathrm{b}}$ & $4.82 \pm 0.27^{\mathrm{A}, \mathrm{b}}$ \\
\hline \multicolumn{5}{|l|}{ Texture } \\
\hline d 15 & $4.10 \pm 0.21^{\mathrm{A}, \mathrm{a}}$ & $4.62 \pm 0.28^{\mathrm{A}, \mathrm{b}}$ & $4.70 \pm 0.32^{\mathrm{A}, \mathrm{b}}$ & $4.30 \pm 0.19^{\mathrm{A}, \mathrm{a}}$ \\
\hline d 30 & $4.40 \pm 0.17^{\mathrm{B}, \mathrm{a}}$ & $4.81 \pm 0.15^{\mathrm{B}, \mathrm{b}}$ & $4.83 \pm 0.18^{\mathrm{A}, \mathrm{b}}$ & $4.39 \pm 0.25^{\mathrm{A}, \mathrm{a}}$ \\
\hline d 60 & $4.63 \pm 0.19^{\mathrm{C}, \mathrm{a}}$ & $4.94 \pm 0.30^{\mathrm{B}, \mathrm{b}}$ & $4.90 \pm 0.16^{\mathrm{A}, \mathrm{b}}$ & $4.58 \pm 0.11^{\mathrm{A}, \mathrm{a}}$ \\
\hline \multicolumn{5}{|l|}{ Odor } \\
\hline d 15 & $4.48 \pm 0.11^{\mathrm{A}, \mathrm{b}}$ & $4.13 \pm 0.20^{\mathrm{A}, \mathrm{a}}$ & $4.02 \pm 0.18^{\mathrm{A}, \mathrm{a}}$ & $4.53 \pm 0.23^{\mathrm{A}, \mathrm{b}}$ \\
\hline d 30 & $4.53 \pm 0.17^{\mathrm{A}, \mathrm{a}}$ & $4.68 \pm 0.31^{\mathrm{B}, \mathrm{ab}}$ & $4.84 \pm 0.22^{\mathrm{B}, \mathrm{b}}$ & $4.93 \pm 0.27^{\mathrm{B}, \mathrm{b}}$ \\
\hline d 60 & $4.66 \pm 0.12^{\mathrm{B}, \mathrm{a}}$ & $4.71 \pm 0.23^{\mathrm{B}, \mathrm{a}}$ & $4.74 \pm 0.29^{\mathrm{B}, \mathrm{a}}$ & $4.95 \pm 0.13^{\mathrm{B}, \mathrm{b}}$ \\
\hline \multicolumn{5}{|l|}{ Flavor } \\
\hline d 15 & $4.02 \pm 0.16^{\mathrm{A}, \mathrm{a}}$ & $4.07 \pm 0.21^{\mathrm{A}, \mathrm{a}}$ & $4.36 \pm 0.13^{\mathrm{A}, \mathrm{b}}$ & $4.53 \pm 0.22^{\mathrm{A}, \mathrm{b}}$ \\
\hline d 30 & $4.12 \pm 0.20^{\mathrm{A}, \mathrm{a}}$ & $4.22 \pm 0.14^{\mathrm{A}, \mathrm{a}}$ & $4.40 \pm 0.19^{\mathrm{A}, \mathrm{b}}$ & $4.66 \pm 0.13^{\mathrm{A}, \mathrm{b}}$ \\
\hline d 60 & $4.33 \pm 0.10^{\mathrm{B}, \mathrm{a}}$ & $4.46 \pm 0.21^{\mathrm{B}, \mathrm{a}}$ & $4.68 \pm 0.18^{\mathrm{B}, \mathrm{b}}$ & $4.93 \pm 0.26^{\mathrm{B}, \mathrm{c}}$ \\
\hline \multicolumn{5}{|l|}{ Overall acceptability } \\
\hline d 15 & $4.28 \pm 0.30^{\mathrm{A}, \mathrm{a}}$ & $4.40 \pm 0.25^{\mathrm{A}, \mathrm{ab}}$ & $4.45 \pm 0.17^{\mathrm{A}, \mathrm{ab}}$ & $4.59 \pm 0.13^{\mathrm{A}, \mathrm{b}}$ \\
\hline d 30 & $4.30 \pm 0.19^{\mathrm{A}, \mathrm{a}}$ & $4.51 \pm 0.10^{\mathrm{A}, \mathrm{ab}}$ & $4.76 \pm 0.20^{\mathrm{B}, \mathrm{b}}$ & $4.69 \pm 0.23^{\mathrm{AB}, \mathrm{b}}$ \\
\hline d 60 & $4.51 \pm 0.16^{\mathrm{A}, \mathrm{a}}$ & $4.68 \pm 0.21^{\mathrm{A}, \mathrm{a}}$ & $4.82 \pm 0.14^{\mathrm{B}, \mathrm{b}}$ & $4.92 \pm 0.29^{\mathrm{B}, \mathrm{b}}$ \\
\hline
\end{tabular}

$\overline{\mathrm{A}, \mathrm{B}}$ Means with different uppercase superscripts differ between ripening times within the same sample $(P<$ $0.05)$.

${ }^{\mathrm{a}-\mathrm{c}}$ Means with different lowercase superscripts differ between treatments within the same ripening time $(P<$ $0.05)$.

${ }^{1}$ Data were analyzed by multifactor ANOVA using the least significant difference test. Values are expressed as mean (of 15 samples) $\pm \mathrm{SD}$.

sonicated at $60 \mathrm{kHz}$. The highest amount of lipolysis and proteolysis occurred on $\mathrm{d} 60$ of the storage period in samples sonicated at $60 \mathrm{kHz}$. Ultrasound at different frequencies did not affect the texture profile of UF white cheese, but ripening time and the interaction of time and sonication frequency significantly affected hardness and gumminess. Ultrasound treatment could improve organoleptic properties due to higher lipolysis and proteolysis.

\section{ACKNOWLEDGMENTS}

This work was part of the $\mathrm{PhD}$ dissertation of $\mathrm{A}$. Jalilzadeh supported by University of Tabriz (Tabriz, Iran). The authors are grateful to Tabriz Pegah Dairy Processing Co. (East Azarbiijan, Tabriz, Iran) for providing production facilities and laboratory space. The authors are also grateful to Hossein Jodeyri (R\&D manager of Tabriz Pegah Dairy Processing Co.) and Depaco laboratory (East Azarbiijan, Tabriz, Iran) for collaborating in this research.

\section{REFERENCES}

Ahmed, S. A., H. R. Wehaidy, O. A. Ibrahim, S. A. El Ghani, and M. A. El-Hofi. 2016. Novel milk-clotting enzyme from Bacillus stea- rothermophilus as a coagulant in UF-white soft cheese. Biocatal. Agric. Biotechnol. 7:241-249.

AOAC International. 1995. Official Methods of Analysis. Vol. II. 16th ed. AOAC International, Arlington, VA.

Ardo, Y., and A. Polychroniadou. 1999. Laboratory Manual for Chemical Analysis of Cheese. Office for Official Publications of the European Communities, Luxembourg.

Arroyo, C., G. Cebrian, R. Pagan, and S. Condon. 2011a. Inactivation of Cronobacter sakazakii by manothermosonication in buffer and milk. Int. J. Food Microbiol. 151:21-28.

Bermúdez-Aguirre, D. A., and G. V. Barbosa-Cánovas. 2008. Study of butter fat content in milk on the inactivation of Listeria innocua ATCC 51742 by thermo-sonication. Innov. Food Sci. Emerg. Technol. 9:176-185.

Bermúdez-Aguirre, D. A., R. Mawson, K. Versteeg, and G. V. Barbosa-Cánovas. 2009. Composition properties, physicochemical characteristics and shelf life of whole milk after thermal and thermosonication treatments. J. Food Qual. 32:283-302.

Bradley, R. L., E. Arnold, D. M. Barbano, R. G. Semerad, D. E. Smith, and B. K. Vines. 1993. Chemical and physical methods. Pages 433-531 in Standard Methods for the Examination of Dairy Products. 16th ed. R. T. Marshall, ed. American Public Health Association, Washington, DC.

Broda, D. M. 2007. The effect of peroxyacetic acid-based sanitizer, heat and ultrasonic waves on the survival of Clostridium estertheticum spores in vitro. Lett. Appl. Microbiol. 45:336-341.

Cameron, M., L. D. McMaster, and T. J. Britz. 2009. Impact of ultrasound on dairy spoilage microbes and milk components. Dairy Sci. Technol. 89:83-98.

Chandrapala, J., G. J. O. Martin, B. Zisu, S. E. Kentish, and M. Ashokkumar. 2012. The effect of ultrasound on casein micelle integrity. J. Dairy Sci. 95:6882-6890.

Collins, Y. F., P. L. McSweeney, and M. G. Wilkinson. 2003. Lipolysis and free fatty acid catabolism in cheese: A review of current knowledge. Int. Dairy J. 13:841-866. 
Cregenzán-Alberti, O., R. M. Halpin, P. Whyte, J. Lyng, and F. Noci. 2014. Suitability of ccRSM as a tool to predict inactivation and its kinetics for Escherichia coli, Staphylococcus aureus and Pseudomonas fluorescens in homogenized milk treated by manothermosonication (MTS). Food Control 39:41-48.

Dewanti, R., and A. C. L. Wong. 1995. Influence of culture conditions on biofilm formation by Escherichia coli O157:H7. Int. J. Food Microbiol. 26:147-164.

Drakopoulou, S., S. Terzakis, M. S. Fountoulakis, D. Mantzavinos, and T. Manios. 2009. Ultrasound-induced inactivation of gramnegative and gram-positive bacteria in secondary treated municipal wastewater. Ultrason. Sonochem. 16:629-634.

Eroglu, A., O. S. Toker, and M. Dogan. 2016. Changes in the texture, physicochemical properties and volatile compound profiles of fresh Kashar cheese ( $<90$ days) during ripening. Int. J. Dairy Technol. 69:243-253.

Evelyn, and F. V. M. Silva. 2015. Use of power ultrasound to enhance the thermal inactivation of Clostridium perfringens spores in beef slurry. Int. J. Food Microbiol. 206:17-23.

Fox, P. F., J. Law, P. L. H. McSweeney, and J. Wallace. 1993. Biochemistry of cheese ripening. Pages 389-438 in Cheese: Chemistry, Physics and Microbiology. Springer US, Philadelphia, PA.

Gao, S., G. D. Lewis, M. Ashokkumar, and Y. Hemar. 2014. Inactivation of microorganisms by low-frequency high-power ultrasound: 2. A simple model for the inactivation mechanism. Ultrason. Sonochem. 21:454-460.

Garde, S., R. Arias, P. Gaya, and M. Nuñez. 2011. Occurrence of Clostridium spp. in ovine milk and Manchego cheese with late blowing defect: Identification and characterization of isolates. Int. Dairy J. $21: 272-278$.

Georgala, A., E. Moschopoulou, A. Aktypis, T. Massouras, E. Zoidou, I. Kandarakis, and E. Anifantakis. 2005. Evolution of lipolysis during the ripening of traditional Feta cheese. Food Chem. 93:73-80.

Goodenough, E. R., and M. Solberg. 1972. A technique for producing large yields of vegetative cell-free refractile Clostridium perfringens spores of unaltered heat resistance. Appl. Microbiol. 23:429-430.

Gunasekaran, S., and M. M. Ak. 2002. Cheese Rheology and Texture. CRC Press, Boca Raton, FL.

Hannon, J. A., S. M. Deutsch, M. N. Madec, J. Y. Gassi, M. P. ChapotChartier, and S. Lortal. 2006. Lysis of starters in UF cheeses: Behaviour of mesophilic lactococci and thermophilic lactobacilli. Int. Dairy J. 16:324-334.

Hayaloglu, A. A., M. Guven, P. F. Fox, and P. L. H. McSweeney. 2005. Influence of starters on chemical, biochemical, and sensory changes in Turkish white-brined cheese during ripening. J. Dairy Sci. 88:3460-3474

Herceg, Z., A. R. Jambrak, V. Lelas, and S. M. Thagard. 2012. The effect of high intensity ultrasound treatment on the amount of Staphylococcus aureus and Escherichia coli in milk. Food Technol. Biotechnol. 50:46-52.

Herceg, Z., A. Režek Jambrak, T. Vukušić, V. Stulić, D. Stanzer, and S. Milošević. 2015. The effect of high-power ultrasound and gas phase plasma treatment on Aspergillus spp. and Penicillium spp. count in pure culture. J. Appl. Microbiol. 118:132-141.

Hesari, J., M. R. Ehsani, A. Khosroshahi, and P. L. McSweeney. 2006. Contribution of rennet and starter to proteolysis in Iranian UF white cheese. Lait 86:291-302.

Hunter, G., M. Lucas, I. Watson, and R. Parton. 2008. A radial mode ultrasonic horn for the inactivation of Escherichia coli K12. Ultrason. Sonochem. 15:101-109.

IDF (International Dairy Federation). 1989. Milk fat Products and Butter. Determination of Fat Acidity. IDF Standard 6B. IDF, Brussels, Belgium.

IDF (International Dairy Federation). 1993. Milk. Determination of the nitrogen (Kjeldahl method) and calculation of the crude protein content. IDF Standard 20B. IDF, Brussels, Belgium.

ISIRI, Institute of Standards and Industrial Research of Iran). 1998. Milk and dairy products - Cheese sensory evaluation test method. National Standard No. 4691. ISIRI, Tehran, Iran.
ISIRI (Institute of Standards and Industrial Research of Iran). 2015. Milk and milk products-Fresh cheese: Specifications and test methods. National Standard No. 6629. ISIRI, Tehran, Iran.

Jambrak, A. R., V. Lelas, T. J. Mason, G. Krešić, and M. Badanjak. 2009. Physical properties of ultrasound treated soy proteins. J. Food Eng. 93:386-393.

Karami, M. 2017. Enhancing the lipolysis of feta-type cheese made from ultrafiltered cow's milk. Lebensm. Wiss. Technol. 80:386-393.

Karami, M., M. R. Ehsani, S. M. Mousavi, K. Rezaei, and M. Safari. 2009. Changes in the rheological properties of Iranian UF-Feta cheese during ripening. Food Chem. 112:539-544.

Kuchroo, C. N., and P. F. Fox. 1982. Soluble nitrogen in cheddar cheese: Comparison of extraction procedures. Milchwissenschaft 37:331-335.

Le Bourhis, A. G., J. Doré, J. P. Carlier, J. F. Chamba, M. R. Popoff, and J. L. Tholozan. 2007. Contribution of C. beijerinckii and $C$. sporogenes in association with $C$. tyrobutyricum to the butyric fermentation in Emmental type cheese. Int. J. Food Microbiol. 113:154-163.

Le Bourhis, A. G., K. Saunier, J. Doré, J. P. Carlier, J. F. Chamba, M. R. Popoff, and J. L. Tholozan. 2005. Development and validation of PCR primers to assess the diversity of Clostridium spp. in cheese by temporal temperature gradient gel electrophoresis. Appl. Environ. Microbiol. 71:29-38.

Li, J., T. Ding, X. Liao, S. Chen, X. Ye, and D. Liu. 2017. Synergetic effects of ultrasound and slightly acidic electrolyzed water against Staphylococcus aureus evaluated by flow cytometry and electron microscopy. Ultrason. Sonochem. 38:711-719.

Marchesini, G., S. Balzan, F. Montemurro, L. Fasolato, I. Andrighetto, S. Segato, and E. Novelli. 2012. Effect of ultrasound alone or ultrasound coupled with $\mathrm{CO}_{2}$ on the chemical composition, cheesemaking properties and sensory traits of raw milk. Innov. Food Sci. Emerg. Technol. 16:391-397.

McSweeney, P. L., and M. J. Sousa. 2000. Biochemical pathways for the production of flavour compounds in cheeses during ripening: A review. Lait 80:293-324.

Nunez, M., C. Garcia-Aser, M. A. Rodriguez-Martin, M. Medina, and P. Gaya. 1986. The effect of ripening and cooking temperatures on proteolysis and lipolysis in Manchego cheese. Food Chem. 21:115123.

Pintado, C. M., M. A. Ferreira, and I. Sousa. 2010. Control of pathogenic and spoilage microorganisms from cheese surface by whey protein films containing malic acid, nisin and natamycin. Food Control 21:240-246.

Piyasena, P. E. Mohareb, and R. C. Mckellar. 2003. Inactivation of microbes using ultrasound: A review. Int. J. Food Microbiol. $87: 207-216$.

Rashidi, H., M. Mazaheri-Tehrani, M. A. Razavi, and M. Ghods-Rohani. 2015. Improving textural and sensory characteristics of lowfat UF feta cheese made with fat replacers. J. Agric. Sci. Technol. $17: 121-132$.

Robinson, R. K. 2014. Microflora of white-brined cheeses. Pages 402 408 in Encyclopedia of Food Microbiology. Vol. 1. 2nd ed. Elsevier Ltd./Academic Press, London, UK.

Sagong, H. G., S. Y. Lee, P. S. Chang, S. Heu, S. Ryu, Y. J. Choi, and D. H. Kang. 2011. Combined effect of ultrasound and organic acids to reduce Escherichia coli O157:H7, Salmonella typhimurium, and Listeria monocytogenes on organic fresh lettuce. Int. J. Food Microbiol. 145:287-292.

Sajadi, K., S. Ian, and S. Bahramian. 2015. Antifungal effect of Aloe vera gel on Penicillium citrinum in culture media and UF cheese. Int. J. Eng. Res. Appl. 1:61-64.

Sanchez, E. S., S. Simal, A. Femenia, J. Benedito, and C. Rosselló. 2001a. Effect of acoustic brining on lipolysis and on sensory characteristics of Mahon cheese. J. Food Sci. 66:892-896.

Sánchez, E. S., S. Simal, A. Femenia, P. Llull, and C. Rosselló. 2001b. Proteolysis of Mahon cheese as affected by acoustic-assisted brining. Eur. Food Res. Technol. 212:147-152.

Sienkiewicz, J. J., A. Wesołowski, W. Stankiewicz, and R. Kotowski. 2017. The influence of ultrasonic treatment on the growth of the 
strains of Salmonella enterica subsp. typhimurium. J. Food Sci. Technol. 54:2214-2223.

Sousa, M. J., Y. Ardö, and P. L. H. McSweeney. 2001. Advances in the study of proteolysis during cheese ripening. Eur. Food Res. Technol. 11:327-345.

Talukdar, P. K., P. Udompijitkul, A. Hossain, and M. R. Sarker. 2017. Inactivation strategies for Clostridium perfringens spores and vegetative cells. Appl. Environ. Microbiol. 83:e02731-16.

Tejada, L., A. Abellán, J. M. Cayuela, A. Martínez-Cacha, and J. Fernández-Salguero. 2008. Proteolysis in goats' milk cheese made with calf rennet and plant coagulant. Int. Dairy J. 18:139-146.

Tsukamoto, I. 2004. Inactivation of Saccharomyces cerevisiae by ultrasonic irradiation. Ultrason. Sonochem. 11:61-65.

Tunick, M. H., K. L. Mackey, P. W. Smith, and V. H. Holsinger. 1991. Effects of composition and storage on the texture of Mozzarella cheese. Neth. Milk Dairy J. 45:117-125.

Uluko, H., S. Zhang, L. Liu, M. Tsakama, J. Lu, and J. Lv. 2015. Effects of thermal, microwave, and ultrasound pretreatments on antioxidative capacity of enzymatic milk protein concentrate hydrolysates. J. Funct. Foods 18:1138-1146.

Villamiel, M., E. H. Van Hamersveld, and P. De Jong. 1999. Effect of ultrasound processing on the quality of dairy products. Milchwissenschaft 54:69-73.
Woo, A. H., S. Kollodge, and R. C. Lindsay. 1984. Quantification of major free fatty acids in several cheese varieties. J. Dairy Sci. $67: 874-878$.

Yang, Z., S. Cao, Y. Cai, and Y. Zheng. 2011. Combination of salicylic acid and ultrasound to control postharvest blue mold caused by Penicillium expansum in peach fruit. Innov. Food Sci. Emerg. Technol. 12:310-314.

Yanjun, S., C. Jianhang, Z. Shuwen, L. Hongjuan, L. Jing, L. Lu, H. Uluko, S. Yanling, C. Wenming, G. Wupeng, and L. Jiaping. 2014. Effect of power ultrasound pre-treatment on the physical and functional properties of reconstituted milk protein concentrate. J. Food Eng. 124:11-18.

Yasar, K., and N. Guzeler. 2011. Effects of coagulant type on the physicochemical and organoleptic properties of Kashar cheese. Int. J. Dairy Technol. 64:372-379.

Zhao, L., S. Zhang, H. Uluko, L. Liu, J. Lu, H. Xue, F. Kong, and J. Lv. 2014. Effect of ultrasound pretreatment on rennet-induced coagulation properties of goat's milk. Food Chem. 165:167-174. 